\title{
Effect of Blended NPS Fertilizer Rates on Dry Fruit Yield and Yield Components of Hot Pepper (Capsicum annuum L.) Varieties at Arba Minch, Southern Ethiopia
}

\author{
Awoke Mensa ${ }^{1,}$, Wassu Mohammed ${ }^{2}$, Kebede Woldetsadik ${ }^{2}$ \\ ${ }^{1}$ South Agricultural Research Institute, Arba Minch Agricultural Research Center, Arba Minch, Ethiopia \\ ${ }^{2}$ School of Plant Sciences, College of Agricultural and Environmental Sciences, Haramaya University, Haramaya, Ethiopia
}

Email address:

awokemensa@gmail.com (A. Mensa)

*Corresponding author

\section{To cite this article:}

Awoke Mensa, Wassu Mohammed, Kebede Woldetsadik. Effect of Blended NPS Fertilizer Rates on Dry Fruit Yield and Yield Components of Hot Pepper (Capsicum annuum L.) Varieties at Arba Minch, Southern Ethiopia. Advances in Biochemistry.

Vol. 9, No. 3, 2021, pp. 74-81. doi: 10.11648/j.ab.20210903.16

Received: May 17, 2021; Accepted: July 5, 2021; Published: August 30, 2021

\begin{abstract}
Hot pepper is one of the most important crops grown by smallholder farmers of Arba Minch Zuria district mainly for income generation. The dry fruit yield of the crop is very low in the district due to several production constraints of which the low accessibility of improved varieties and soil nutrient deficiency are among the major ones. Therefore, this experiment was conducted at Chano Mille Kebele, Arba Minch Zuria district of Southern Ethiopia during 2018/2019 cropping season to assess the effect of blended NPS fertilizer rates on growth, yield and yield components of hot pepper varieties and to determine optimum rate(s) of blended NPS fertilizer for hot pepper production for the study area. Six rates of blended NPS fertilizer $(0$, 50, 100, 150, 200 and $250 \mathrm{~kg} \mathrm{ha}^{-1}$ ) and three hot pepper varieties (Bako Local, Mareko Fana and Melka Shote) were used as experimental treatments and laid-out in 3x6 factorial arrangement in Randomized Complete Block Design in three replications. The results revealed that the main effect of variety and rates of blended NPS fertilizer had a significant effect $(\mathrm{P}<0.05)$ on growth, yield and yield components of hot pepper. The interaction effect of variety and rates of blended NPS fertilizer significantly affected the yield and yield components of hot pepper but not growth parameters. Melka Shote variety showed better vegetative growth. Melka Shote and Bako Local at the application of $200 \mathrm{~kg} \mathrm{ha}^{-1}$ blended NPS fertilizer produced large number of fruits plant ${ }^{-1}$ and seeds fruit ${ }^{-1}$, maximum fruit weight plant ${ }^{-1}$ and dry fruit yield without significant variation among the two treatment combinations. Regression analysis revealed that as application of blended NPS fertilizer increased by one $\mathrm{kg}$, the total dry fruit yield of Bako Local, Mareko Fana and Melka Shote increased by 7.3, 6.2 and $8.6 \mathrm{~kg}$, respectively. Melka Shote variety had dry fruit yield advantage of 1.3 and $2.4 \mathrm{~kg}$ over Bako Local and Mareko Fana, respectively, as the rates of blended NPS fertilizer increased by one $\mathrm{kg}$. Thus, application of $200 \mathrm{~kg} \mathrm{ha}^{-1}$ blended NPS fertilizer for Melka Shote and Bako Local varieties could be optimum and recommended to improve hot pepper productivity for the current soil fertility status of the study area and vicinity with similar soil fertility status and agro-ecology.
\end{abstract}

Keywords: Blended Fertilizer, Hot Pepper, Regression, Linear Relationship, Fruit Yield, Soil Fertility

\section{Introduction}

Hot pepper (Capsicum annuum L.) is the most important crop consumed as vegetable (green fruit) and spice (dry fruit) in the world [1]. Due to its multiple uses in the Ethiopian daily diet, hot pepper is an important crop mainly valued for its pungency and color. According to Ethiopian Export Promotion Agency [2] report, hot pepper is a high value and important cash-generating commodity for small-scale farmers in Ethiopia.

In Ethiopia, total green and dry fruit yield production of hot pepper was $62,247.56$ and $307,457.11$ tons, respectively from an area of 10,473.07 and 172,142.19ha, respectively in 2018/2019 cropping season [3]. Hot pepper production has remained low in the country with a national average yield of 5.7 and 1.9 tons $\mathrm{ha}^{-1}$ for green and dry fruit yield, 
respectively [3]. Diseases and insect pests, lack of improved varieties, lack of appropriate and optimum fertilizer recommendation and moisture stress are the most significant constraints that affect hot pepper production in Ethiopia [48]. Moreover, soil nutrient deficiency and low accessibility of improved varieties are among the most critical factors that limit the yield and production of hot pepper in Arba Minch Zuria District, Southern Ethiopia [9].

According to early report, most Ethiopian soils are deficient in nitrogen $(\mathrm{N})$ and phosphorus $(\mathrm{P})$ and source of inorganic fertilizer application has been only Di-ammonium phosphate and Urea, which are limited to N and P [10]. However, the recent reports revealed that most Ethiopian soils lack four macronutrients such as N, P, Sulfur (S) and Potassium (K) and also other three micronutrients namely; Zinc, Boron and Copper [11]. More specifically, the soil of low land areas of Arba Minch Zuria District is mainly deficient in N,P and S nutrients [12]. As a result, the Ethiopian Agricultural Transformation Agency and Ethiopia Soil Information System jointly suggested the importance of balanced application of macro and micro nutrients for the improvement of soil fertility management through blended fertilizers (NPS, NPSB, NPSZnB, etc...) to improve crop production in Southern Ethiopia particularly in Arba Minch Zuria District [12].

However, optimum rate of blended NPS fertilizer is not determined for hot pepper production in the study area (Arba
Minch). Additionally, the response of hot pepper to blended NPS fertilizer application was not assessed yet and it differs with varieties, soil type, agronomic practices and soil fertility status of a given locality. Thus, there is a need to identify high yielding hot pepper variety and optimum blended NPS fertilizer rate to increase the productivity of hot pepper in the study area. Therefore, this study was conducted to assess the effect of blended NPS fertilizer rates on growth, yield components and dry fruit yield of hot pepper varieties and to determine optimum blended NPS fertilizer rate(s) for hot pepper production at Arba Minch, Southern Ethiopia.

\section{Materials and Methods}

\subsection{Description of the Study Area}

The experiment was conducted at Chano Mille, Arba Minch Zuria District of Gamo Zone (formerly known as Gamo Gofa Zone), Southern Ethiopia from July 2018 to February 2019 in the 2018/2019 cropping season under supplementary irrigation (Figure 1). The study site is located about $500 \mathrm{~km}$ South of Addis Ababa, the capital city of Ethiopia, at an altitude of 1220 meter above sea level. The area received average rainfall of $320.1 \mathrm{~mm}$ with the minimum and maximum temperature of 17.2 and $31.3^{\circ} \mathrm{C}$, respectively during the experimental period (July 2018-February 2019) [13].

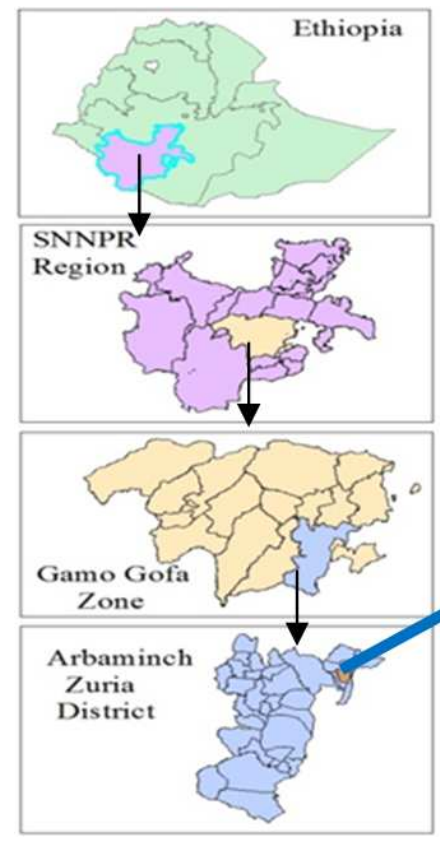

\subsection{Experimental Materials}

Three hot pepper varieties namely; Bako Local, Mareko Fana and Melka Shote were used. These varieties were selected for their high yielding, adapted to different soil types and widely produced in the country. Moreover, the varieties are highly preferred by the farming and purchasing

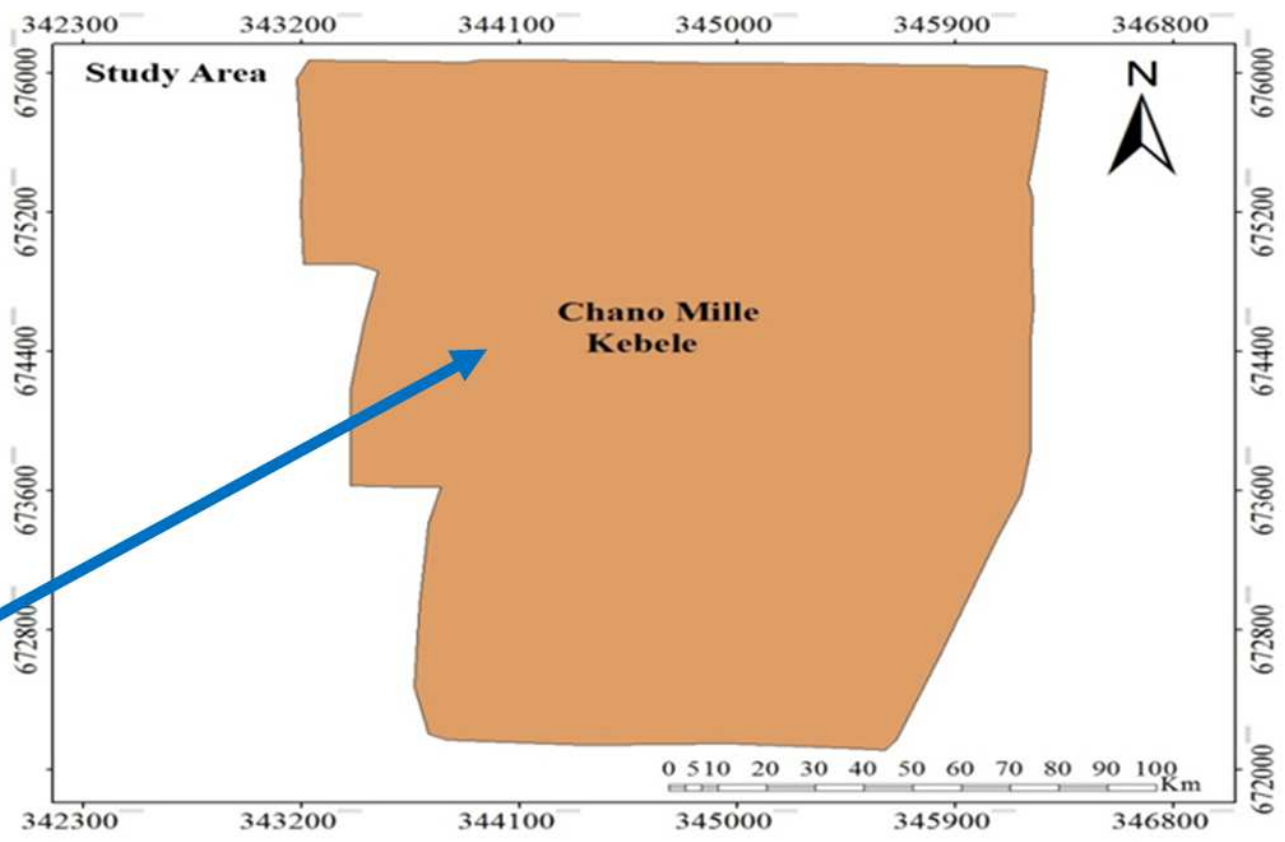

Figure 1. Map of study area.

communities owing to their pungency level, attractive color, and high green and dry fruit yield. The varieties were released with their desirable characters such as light and dark red pungent fruits; and growing well at wider range of altitudes $[14,15]$. Urea $(46 \% \mathrm{~N})$ and NPS $(19 \% \mathrm{~N}, 38 \% \mathrm{P}$, and $7 \% \mathrm{~S}$ ) were used as the sources of inorganic fertilizer (Table 5). 


\subsection{Soil Sampling and Analysis}

Soil samples were taken before planting in zigzag pattern randomly from the experimental site at a depth of $0-30 \mathrm{~cm}$ using an auger. The samples were mixed thoroughly to produce one representative composite sample. About a kilo gram of composite sample was taken using polyethylene bag and analyzed for selected physicochemical properties such as soil texture, soil $\mathrm{pH}$, total $\mathrm{N}$, available $\mathrm{P}$, available $\mathrm{S}$, organic carbon (OC) and cation exchange capacity (CEC) by using the appropriate laboratory procedures.

\subsection{Experimental Treatments, Design and Procedures}

The experiment was consisted of three hot pepper varieties (Bako Local, Mareko Fana and Melka Shote) and six rates of blended NPS fertilizer $\left(0,50,100,150,200\right.$ and $\left.250 \mathrm{~kg} \mathrm{ha}^{-1}\right)$. These treatment combinations were laid-out in $3 \times 6$ factorial arrangement in Randomized Complete Block Design with three replications. Three seedbeds $(1 \mathrm{~m}$ width and $5 \mathrm{~m}$ length for each variety, leaving $1 \mathrm{~m}$ space between the seedbeds) were well prepared for three hot pepper varieties two weeks before sowing. Seeds were drilled on rows spaced $0.15 \mathrm{~m}$ apart on July 2, 2018 and seedbeds were mulched (with dry grass) and provided with water through fine watering cane (twice a day, early morning and late afternoon) until the seeds germinate. After seeds germinated, the mulch was removed, watering the seedlings continued, shades were constructed at a height of $1.5 \mathrm{~m}$ and hand weeding applied on each seedbed for better seedling growth.

Seedlings were hardened-off through removing the shades and reducing water application (once in two days) for one week before transplanting. Seedlings of the three hot pepper varieties were ready for transplanting after six weeks of seeds sown. From each variety, healthy and vigor seedlings with uniform height were selected and transplanted. The recommended intra and inter row spacing $(0.3$ and $0.7 \mathrm{~m}$, respectively) was maintained for the main experimental field [14]. The experimental plot size was $2.8 \mathrm{~m}$ width and $3.6 \mathrm{~m}$ length and space between plots and blocks was $0.75 \mathrm{~m}$ and $1.5 \mathrm{~m}$, respectively. There were four rows in each plot and twelve plants per row with a total of 48 plants per plot. One outermost row on each side of a plot was considered as border. Thus, the remaining two middle rows in each plot were considered for the data collection on plant basis.

Based on the treatments proposed, whole quantity of blended NPS fertilizer was applied during transplanting. The recommended Urea at $100 \mathrm{~kg} \mathrm{ha}^{-1}$ was also applied in split (50\% at transplanting and the remaining $50 \%$ at 40 days after transplanting) for all plots except for the control. Weeding, supplementary irrigation and other agronomic practices were uniformly performed for all plots as recommended by EARO [14] for the production of hot pepper.

\subsection{Data Collection and Analysis}

Data were collected from both plot and plant basis. Data such as plant height, branch number plant ${ }^{-1}$, canopy diameter, number of fruits plant ${ }^{-1}$ and average dry fruit weight plant ${ }^{-1}$ were collected on plant basis from ten randomly selected plants in the central two rows whereas number of seeds fruit ${ }^{-1}$, thousand seeds weight and dry fruit yield (marketable, unmarketable and total dry fruit yield) were collected from plot basis. The unmarketable dry fruit yield was recorded through subjective judgment based on shrunken shaped fruits, small sized and discolored fruits that were estimated to be due to the differences in varieties and rates of fertilizer applied.

The collected data were subjected to analysis of variance (ANOVA) using SAS statistical software package version 9.2 [16]. Means that differed significantly were separated by using Duncan Multiple Range Test (DMRT) at 5\% significance level. Regression analysis was conducted taking total dry fruit yield as the dependent variable and rates of blended NPS fertilizer as an independent variable to determine the rate of yield increase as the change of the rates of blended NPS fertilizer.

\section{Results and Discussion}

\subsection{Soil Physico-chemical Properties of Experimental Site}

The pre-transplanting soil analysis result revealed that the soil of experimental field is clay with slightly alkaline, moderate in organic carbon, organic matter and total nitrogen but very low and low in available phosphorus and sulfur, respectively (Table 1).

Table 1. Pre-planting soil physico-chemical properties of the experimental site during 2018/2019 cropping season.

\begin{tabular}{lll}
\hline Soil physico-chemical properties & Result & Status \\
\hline Clay $(\%)$ & 71.46 & - \\
Silt $(\%)$ & 26.52 & - \\
Sand $(\%)$ & 2.02 & - \\
Textural class & - & Clay \\
pH $\left(1: 2.5, \mathrm{H}_{2} \mathrm{O}\right)$ & 7.60 & Slightly alkaline \\
$\mathrm{OC}(\%)$ & 1.37 & Low \\
OM $(\%)$ & 2.36 & Moderate \\
Total N $(\%)$ & 0.28 & Moderate \\
Available P $\left(\mathrm{mg} \mathrm{kg}^{-1}\right)$ & 3.35 & Very low \\
Available S $\left(\mathrm{mg} \mathrm{kg}^{-1}\right)$ & 17.45 & Low \\
CEC $(\mathrm{cmol} \mathrm{kg})$ & 27.10 & High \\
\hline
\end{tabular}

$\mathrm{pH}=$ power of hydrogen; $\mathrm{OC}=$ Organic carbon; $\mathrm{OM}=$ Organic matter; $\mathrm{N}=$ Nitrogen; $\mathrm{P}=$ Phosphorus; $\mathrm{S}=$ Sulfur; $\mathrm{CEC}=$ Cation exchange capacity.

\subsection{Growth of Hot Pepper}

The growth parameters of hot pepper were significantly influenced by variety and rates of blended NPS fertilizer application. However, the interaction of variety and rates of blended NPS fertilizer did not affect the growth parameters of the crop. Melka Shote had significantly tallest plants, widest canopy diameter and highest number of primary branches plant ${ }^{-1}$ while Mareko Fana had significantly shortest plants, narrowest canopy diameter and minimum number of primary branches plant ${ }^{-1}$ (Table 2). The difference in growth parameters showed that genetic difference is responsible to determine the growth performance of the variety in a given area. Hence, Melka Shote showed an overall encouraging 
performance in terms of growth parameters as compared to Bako Local and Mareko Fana varieties.

It was indicated that the presence of significant variation among hot pepper varieties in terms of growth characters (plant height, canopy growth, and branching habit) were influenced by the inherent characters of the cultivars, space availability, nutrient availability and weather condition [15]. Kahsay [17] also reported that growth parameters (number of branches plant $^{-1}$, canopy width and plant height) were significantly affected by pepper cultivars.

Significant differences were also observed among blended NPS fertilizer rates on growth traits of hot pepper. Accordingly, hot pepper plants grown at the application of highest $\left(250 \mathrm{~kg} \mathrm{ha}^{-1}\right)$ rate of blended NPS fertilizer had significantly tallest plants and maximum number of primary branches plant $^{-1}$ whereas plants grown without fertilizer application produced significantly shortest plants and minimum number of branches plant ${ }^{-1}$. Hot pepper plants had widest canopy when grown at the application of 150, 200 and $250 \mathrm{~kg} \mathrm{ha}^{-1}$ blended NPS fertilizer without significant difference among the three rates whereas plants grown without blended NPS fertilizer had significantly narrowest canopy diameter (Table 2). It was also observed that as the rates of blended NPS fertilizer increased, plant height, canopy diameter and primary branch of hot pepper also increased.

The increase in growth parameters at the highest blended NPS fertilizer rate might have been resulted from improved root growth and increased uptake of nutrients, better growth and active cell division favored due to synergetic effect of the three nutrients (NPS) and availability of adequate nutrients at the highest rate. In line with this, El-Tohamy et al. [18] reported that sulfur application plays important roles to improve the availability of other essential nutrients such as $\mathrm{P}$, $\mathrm{K}, \mathrm{Zn}, \mathrm{Mn}$ and $\mathrm{Cu}$. Similarly, Awodun et al. [19] also reported that NPK fertilizer significantly increased growth parameters of pepper. Moreover, Rizvi et al. [20] reported that combined application of $\mathrm{N}$ and $\mathrm{P}_{2} \mathrm{O}_{5}$ at the rate of 140 and $60 \mathrm{~kg} \mathrm{ha}^{-1}$ resulted in the widest plant canopy of chili pepper in Dhaka, Bangladesh.

Table 2. Main effect of variety and blended NPS fertilizer rates on growth parameters of hot pepper varieties evaluated at Arba Minch during 2018/2019 cropping season.

\begin{tabular}{llll}
\hline Treatments & Growth parameters & & \\
\hline & Plant height $(\mathbf{c m})$ & Canopy diameter $(\mathbf{c m})$ & Number of primary branches per plant \\
\hline Variety & & & \\
Bako Local & $62.62^{\mathrm{b}}$ & $37.15^{\mathrm{b}}$ & $7.60^{\mathrm{b}}$ \\
Mareko Fana & $57.63^{\mathrm{c}}$ & $32.72^{\mathrm{c}}$ & $6.00^{\mathrm{c}}$ \\
Melka Shote & $67.53^{\mathrm{a}}$ & $48.53^{\mathrm{a}}$ & $9.50^{\mathrm{a}}$ \\
NPS rate $\left(\mathrm{kg} \mathrm{ha}^{-1}\right)$ & & \\
0 & $50.57^{\mathrm{d}}$ & $32.07^{\mathrm{c}}$ & $5.40^{\mathrm{d}}$ \\
50 & $57.92^{\mathrm{c}}$ & $35.32^{\mathrm{bc}}$ & $5.80^{\mathrm{cd}}$ \\
100 & $63.64^{\mathrm{b}}$ & $36.55^{\mathrm{b}}$ & $6.60^{\mathrm{c}}$ \\
150 & $64.07^{\mathrm{b}}$ & $41.86^{\mathrm{a}}$ & $8.70^{\mathrm{b}}$ \\
200 & $66.21^{\mathrm{b}}$ & $45.04^{\mathrm{a}}$ & $9.30^{\mathrm{b}}$ \\
250 & $73.14^{\mathrm{a}}$ & $45.96^{\mathrm{a}}$ & $10.40^{\mathrm{a}}$ \\
CV (\%) & 8.50 & 10.40 & 13.10 \\
\hline
\end{tabular}

Mean values in each category of each column shared the same letter(s) are statistically not different by DMRT at 5\% probability level. CV $=$ Coefficient of variation in percent.

\subsection{Yield Components of Hot Pepper}

The yield components of hot pepper were significantly $(\mathrm{P}<0.05)$ influenced by both the main and interaction effects of variety and rates of blended NPS fertilizer. Melka Shote variety at the application of $200 \mathrm{~kg} \mathrm{ha}^{-1}$ blended NPS fertilizer produced the highest number of fruits plant ${ }^{-1}$, average dry fruit weight plant $^{-1}$ and seeds fruit ${ }^{-1}$ (Table 3). Mareko Fana and Melka Shote varieties produced the lowest number of fruits plant ${ }^{-1}$, average dry fruit weight plant $^{-1}$ and number of seeds fruit ${ }^{-1}$ at $0 \mathrm{~kg} \mathrm{ha}^{-1}$ of blended NPS fertilizer without significant variation among the two treatment combinations. Application of $200 \mathrm{~kg}$ NPS ha ${ }^{-1}$ for Melka Shote variety increased the number of seeds fruit ${ }^{-1}$ by $14.76 \%$ and $9.45 \%$ as compared to Mareko Fana and Bako Local varieties, respectively treated alike. It was observed that as the rates of blended NPS fertilizer increased up to $200 \mathrm{~kg} \mathrm{ha}^{-1}$ across each variety so did the yield components of hot pepper though the relationship had inconsistencies and not linear in some other parameters (Table 3 ). These revealed that the varieties are highly responsive to the applied blended NPS fertilizer rates.

These indicate that application of blended NPS fertilizer in nutrient deficient soil is essential to encourage the growth of yield- contributing traits of hot pepper varieties. This might be due to sufficient availability of macronutrients through blended NPS fertilizer application coupled with varietal genetic potential, which enables the plants to acquire better yield components. Therefore, this could suggest that adequate supply of essential nutrients through optimum application of blended NPS fertilizer for hot pepper varieties play a significant role in improving their yield components.

These results are in line with Kassa et al. [21] who reported that combined application of $\mathrm{N}$ and $\mathrm{P}$ had significant effect on number of fruits plant ${ }^{-1}$ in hot pepper. Kanneh et al. 
[22] in Sierra Leone also observed that the number of fruits plant $^{-1}$ and fruit weight were directly related to the amount of nutrients applied in pepper varieties. According to Zaki et al. [23], application of phosphorous at the rate of $75 \mathrm{~kg} \mathrm{ha}^{-1}$ increased the number of fruits plant $^{-1}$ for the Marconi sweet pepper variety in Egypt. Moreover, application of inorganic fertilizer that contains sulfur nutrient improved yield components of chili [24]. Uchida [25] stated that adequate supply of essential nutrients is important for vigorous vegetative growth, thereby better seed formation of pepper; in contrast, lack of macronutrients resulted in poor seed development thereby minimum seed number obtained and subsequently reduced yield.

Table 3. Interaction effect of variety and blended NPS fertilizer rates on number of fruits plant ${ }^{-1}$, average dry fruit weight plant ${ }^{-1}$, number of seeds fruit ${ }^{-1}$ and 1000 seeds weight of hot pepper varieties evaluated at Arba Minch during 2018/2019 cropping season.

\begin{tabular}{|c|c|c|c|c|c|}
\hline Variety & NPS rate $\left(\mathrm{kg} \mathrm{ha}^{-1}\right)$ & $\begin{array}{l}\text { Number of fruits } \\
\text { plant }^{-1}\end{array}$ & $\begin{array}{l}\text { Average dry fruit weight } \\
\text { plant }^{-1}(\mathrm{~g})\end{array}$ & $\begin{array}{l}\text { Number of seeds } \\
\text { fruit }^{-1}\end{array}$ & $\begin{array}{l}\text { Thousand seeds weight } \\
\text { (g) }\end{array}$ \\
\hline \multirow[t]{6}{*}{ Bako Local } & 0 & $27.13^{\mathrm{hi}}$ & $28.74^{\mathrm{fg}}$ & $79.00^{\text {gh }}$ & $4.66^{\mathrm{ikl}}$ \\
\hline & 50 & $30.60^{\mathrm{h}}$ & $33.04^{\text {ef }}$ & $88.00^{\mathrm{g}}$ & $5.33^{\text {ghi }}$ \\
\hline & 100 & $35.45^{\mathrm{g}}$ & $37.33^{\mathrm{e}}$ & $108.90^{\text {de }}$ & $5.33^{\text {ghi }}$ \\
\hline & 150 & $41.61^{\mathrm{ef}}$ & $54.59^{\mathrm{bc}}$ & $112.50^{\text {cd }}$ & $6.67^{\mathrm{ef}}$ \\
\hline & 200 & $46.22^{\mathrm{cd}}$ & $70.00^{\mathrm{a}}$ & $129.40^{\mathrm{b}}$ & $8.33^{\mathrm{a}}$ \\
\hline & 250 & $35.37^{\mathrm{g}}$ & $59.56^{\mathrm{b}}$ & $103.00^{\text {ef }}$ & $7.00^{\mathrm{def}}$ \\
\hline \multirow[t]{6}{*}{ Mareko Fana } & 0 & $21.00^{\mathrm{j}}$ & $25.85^{\mathrm{fg}}$ & $82.50^{\text {gh }}$ & $3.67^{\mathrm{m}}$ \\
\hline & 50 & $23.76^{\mathrm{ij}}$ & $28.08^{\mathrm{fg}}$ & $98.30^{\mathrm{f}}$ & $5.67^{\mathrm{gh}}$ \\
\hline & 100 & $29.53^{\mathrm{h}}$ & $33.70^{\text {ef }}$ & $118.70^{\text {cd }}$ & $6.00^{\mathrm{g}}$ \\
\hline & 150 & $38.14^{\mathrm{fg}}$ & $40.74^{\mathrm{e}}$ & $118.00^{\mathrm{cd}}$ & $7.33^{\mathrm{bcd}}$ \\
\hline & 200 & $44.31^{\mathrm{de}}$ & $56.00^{\mathrm{bc}}$ & $121.80^{\mathrm{bc}}$ & $8.00^{\mathrm{ab}}$ \\
\hline & 250 & $41.66^{\mathrm{ef}}$ & $55.78^{\mathrm{bc}}$ & $115.50^{\mathrm{cd}}$ & $7.33^{\mathrm{bcd}}$ \\
\hline \multirow[t]{6}{*}{ Melka Shote } & 0 & $22.86^{\mathrm{j}}$ & $23.41^{\mathrm{g}}$ & $77.00^{\mathrm{h}}$ & $4.33^{1}$ \\
\hline & 50 & $30.16^{\mathrm{h}}$ & $40.26^{\mathrm{e}}$ & $86.50^{\text {gh }}$ & $5.00^{\mathrm{hijk}}$ \\
\hline & 100 & $38.12^{\mathrm{fg}}$ & $41.63^{\mathrm{de}}$ & $97.90^{\mathrm{f}}$ & $5.33^{\text {ghij }}$ \\
\hline & 150 & $50.40^{\mathrm{b}}$ & $49.19^{\text {cd }}$ & $114.00^{\mathrm{cd}}$ & $4.33^{\mathrm{kl}}$ \\
\hline & 200 & $59.85^{\mathrm{a}}$ & $74.81^{\mathrm{a}}$ & $142.90^{\mathrm{a}}$ & $7.67^{\mathrm{bc}}$ \\
\hline & 250 & $49.22^{\mathrm{bc}}$ & $70.37^{\mathrm{a}}$ & $118.10^{\text {cd }}$ & $5.67^{\mathrm{gh}}$ \\
\hline CV (\%) & & 6.10 & 4.50 & 5.00 & 6.30 \\
\hline
\end{tabular}

Mean values in each column shared the same letter(s) are not statistically different by DMRT at $5 \%$ probability level. CV (\%) $=$ Coefficient of variation in percent.

\subsection{Dry Fruit Yield}

Both the main and interaction effects of variety and rates of blended NPS fertilizer significantly affected the marketable, unmarketable and total dry fruit yield of hot pepper. Accordingly, the maximum marketable (3.29 tha $\left.{ }^{1}\right)$ and total $\left(3.37 \mathrm{t} \mathrm{ha}^{-1}\right)$ dry fruit yield and minimum unmarketable dry fruit yield were obtained from Melka Shote variety at the application of $200 \mathrm{~kg} \mathrm{ha}^{-1}$ blended NPS fertilizer without significant variation with Bako Local at the same rate. On the other hand, minimum marketable and total dry fruit yield were harvested from plots that received $0 \mathrm{~kg} \mathrm{ha}^{-1}$ of blended NPS fertilizer across the three varieties without significant variation between the treatment combinations. When $200 \mathrm{~kg} \mathrm{ha}^{-1}$ of blended NPS fertilizer applied to Melka Shote variety, marketable and total dry fruit yield were increased by 77.81 and $68.73 \%$, respectively as compared with the same variety when no fertilizer applied and by 27.75 and $25.07 \%$, respectively as compared to Mareko Fana variety at the same fertilizer rate (i.e. $200 \mathrm{~kg} \mathrm{NPS} \mathrm{ha}^{-1}$ ) (Table 4). The fertilizer response curve indicated that increasing the rates of blended NPS fertilizer application from zero to $200 \mathrm{~kg} \mathrm{ha}^{-1}$ consistently increased the total dry fruit yield across the three varieties and then started to decrease with rates increased (Figure 2). The marketability of dry fruit yield from Melka Shote variety at the application of 200 $\mathrm{kg} \mathrm{ha}^{-1}$ blended NPS fertilizer was increased by $76.47 \%$ as compared to control ( $\left.0 \mathrm{~kg} \mathrm{NPS} \mathrm{ha}{ }^{-1}\right)$ whereas that of Bako Local at $200 \mathrm{~kg}$ NPS ha ${ }^{-1}$ by $74.74 \%$ over the control (Table 4). The better dry fruit yield of Melka Shote and Bako Local at $200 \mathrm{~kg}$ NPS ha ${ }^{-1}$ might be due to better nutrient use efficiency of the variety, availability and uptake of macronutrients increased through optimum blended NPS fertilizer application to nutrient deficient soil as a result the varieties increased their fruit yield. Moreover, it is might be due to the increase in yield attributing traits (number of fruits plant ${ }^{-1}$, highest fruit weight plant $^{-1}$ and seed numbers fruit ${ }^{-1}$ ) of the two varieties (Bako Local and Melka Shote) at optimum rate of blended NPS fertilizer application $\left(200 \mathrm{~kg} \mathrm{ha}^{-1}\right)$. The highest unmarketable dry fruit yield obtained from the three varieties at zero and lower rates of NPS fertilizer could be attributed to deficiency and/or insufficient of nutrients in the soil resulted in weak growth of plants and smaller size of fruits, which were witnessed during field condition. Wakuma [26], and Fufa and Abera [27] reported similar results in their study, which is response of hot pepper cultivars to blended fertilizer types (NPSBZn and NPSB) and rates at Raya Azebo (Northern Ethiopia) and Assosa (Western Ethiopia) conditions, respectively. 
Table 4. Interaction effect of variety and rates of blended NPS fertilizer on dry fruit yield of hot pepper varieties evaluated at Arba Minch during 2018/2019 cropping season.

\begin{tabular}{|c|c|c|c|c|}
\hline Variety & NPS rate $\left(\mathrm{kg} \mathrm{ha}^{-1}\right)$ & Marketable dry fruit yield $\left(\mathrm{t} \mathrm{ha}^{-1}\right)$ & Unmarketable dry fruit yield $\left(\mathrm{t} \mathrm{ha}^{-1}\right)$ & Total dry fruit yield $\left(\mathrm{t} \mathrm{ha}^{-1}\right)$ \\
\hline \multirow[t]{6}{*}{ Bako Local } & 0 & $0.91^{\text {gh }}$ & $0.38^{\mathrm{a}}$ & $1.29^{\text {ghi }}$ \\
\hline & 50 & $1.22^{\mathrm{efg}}$ & $0.26^{\mathrm{c}}$ & $1.49^{\mathrm{fgh}}$ \\
\hline & 100 & $1.45^{\mathrm{de}}$ & $0.23^{\mathrm{de}}$ & $1.68^{\mathrm{ef}}$ \\
\hline & 150 & $2.34^{\mathrm{b}}$ & $0.12^{\mathrm{ij}}$ & $2.46^{\mathrm{b}}$ \\
\hline & 200 & $3.05^{\mathrm{a}}$ & $0.10^{\mathrm{jk}}$ & $3.15^{\mathrm{a}}$ \\
\hline & 250 & $2.53^{\mathrm{b}}$ & $0.15^{\mathrm{h}}$ & $2.68^{\mathrm{b}}$ \\
\hline \multirow[t]{6}{*}{ Mareko Fana } & 0 & $0.91^{\mathrm{gh}}$ & $0.25^{\mathrm{c}}$ & $1.16^{\mathrm{i}}$ \\
\hline & 50 & $1.00^{\mathrm{fgh}}$ & $0.26^{\mathrm{c}}$ & $1.26^{\mathrm{hi}}$ \\
\hline & 100 & $1.30^{\mathrm{ef}}$ & $0.22^{\text {def }}$ & $1.52^{\mathrm{fg}}$ \\
\hline & 150 & $1.63^{\mathrm{cd}}$ & $0.20^{\text {defg }}$ & $1.83^{\mathrm{de}}$ \\
\hline & 200 & $2.38^{\mathrm{b}}$ & $0.14^{\mathrm{hi}}$ & $2.52^{\mathrm{b}}$ \\
\hline & 250 & $2.41^{\mathrm{b}}$ & $0.10^{\mathrm{jk}}$ & $2.51^{\mathrm{b}}$ \\
\hline \multirow[t]{6}{*}{ Melka Shote } & 0 & $0.73^{\mathrm{h}}$ & $0.32^{\mathrm{b}}$ & $1.05^{\mathrm{i}}$ \\
\hline & 50 & $1.72^{\text {cd }}$ & $0.26^{\mathrm{c}}$ & $1.98^{\mathrm{cd}}$ \\
\hline & 100 & $1.92^{\mathrm{c}}$ & $0.23^{\mathrm{d}}$ & $2.14^{\mathrm{c}}$ \\
\hline & 150 & $2.31^{\mathrm{b}}$ & $0.20^{\text {defg }}$ & $2.51^{\mathrm{b}}$ \\
\hline & 200 & $3.29^{\mathrm{a}}$ & $0.08^{k}$ & $3.37^{\mathrm{a}}$ \\
\hline & 250 & $2.98^{\mathrm{a}}$ & $0.18^{\mathrm{g}}$ & $3.17^{\mathrm{a}}$ \\
\hline CV (\%) & & 9.60 & 7.30 & 6.50 \\
\hline
\end{tabular}

Means in each column shared similar letter(s) are not significantly different by DMRT at $5 \%$ probability level. CV $(\%)=$ Coefficient of variation in percent.

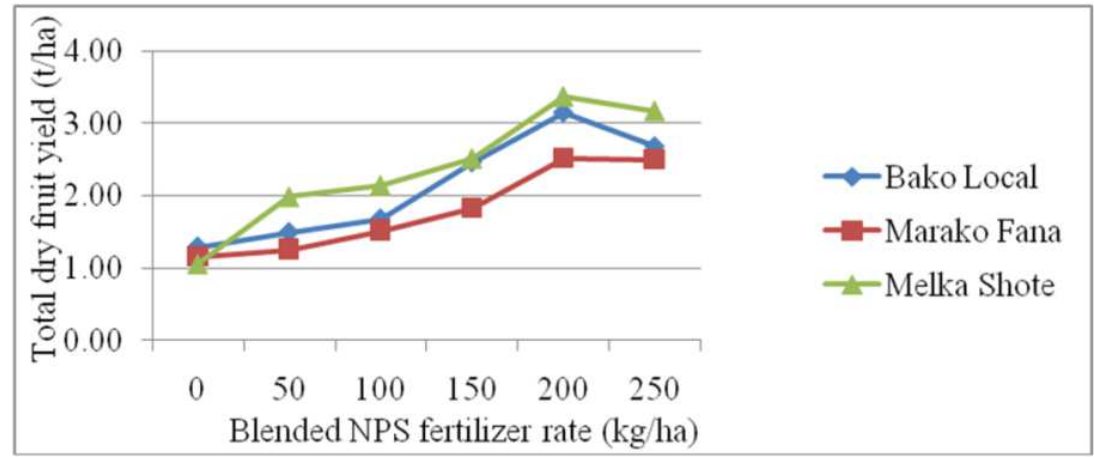

Figure 2. Fertilizer response curve of hot pepper varieties to rates of blended NPS fertilizer at Arba Minch during 2018/2019 cropping season.

\subsection{Regression Analysis}

Total dry fruit yield response of three hot pepper varieties to rates of blended NPS fertilizer was presented in Figure 3. Total dry fruit yield of the three varieties increased as the rates of blended NPS fertilizer increased; the linear relationship was observed between the rates of blended NPS fertilizer and total dry fruit yield of varieties. The coefficient of determination $\left(\mathrm{r}^{2}\right)$ was $0.833,0.930$ and 0.953 for Bako Local, Mareko Fana and Melka Shote, respectively. This indicated that the total dry fruit yield of Bako Local, Mareko Fana and Melka Shote was determined by 83.3, 93.0 and $95.3 \%$, respectively due to the application of blended NPS fertilizer as increased from zero to $250 \mathrm{~kg} \mathrm{ha}^{-1}$. The rates of blended NPS fertilizer and total dry fruit yield of Bako Local, Mareko Fana, and Melka Shote had a strong and positive correlation of $\mathrm{r}=0.913, \mathrm{r}=0.964$ and $\mathrm{r}=0.953$, respectively. The total dry fruit yield of Melka Shote was highest both at lower and higher rates of blended NPS fertilizer while
Mareko Fana variety had lowest both at lower and higher rates of blended NPS fertilizer. The regression equation revealed that as the application of blended NPS fertilizer increased by one $\mathrm{kg}$, the total dry fruit yield of Bako Local, Mareko Fana and Melka Shote increased by 7.3, 6.2 and 8.6 $\mathrm{kg}$, respectively (Figure 3).

The results from the regression equation and information from the scatter plot indicated that production of Melka Shote variety had an advantage for growers because as the application rates of NPS fertilizer increased, the grower would obtain more yield than from the other two varieties (Figure 3). Melka Shote variety had dry fruit yield advantages of 1.3 and $2.4 \mathrm{~kg}$ over Bako Local and Mareko Fana, respectively as the rates of blended NPS fertilizer increased by one $\mathrm{kg}$. The results also showed that the growers could estimate the total dry fruit yield by the amount of blended NPS fertilizer applied and could make a decision on how many kilograms of NPS fertilizer to apply in order to obtain planned yield per unit area. 


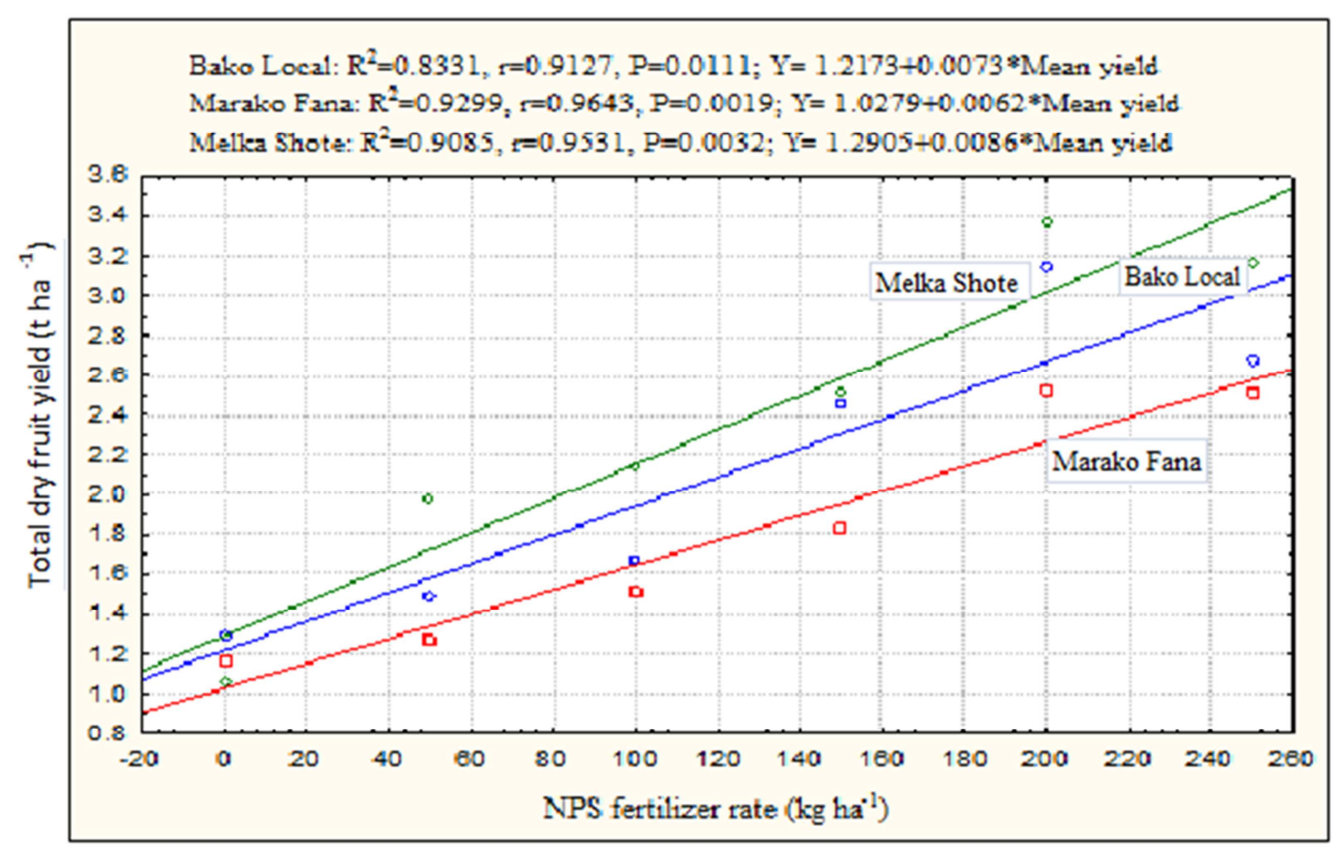

Figure 3. Scatter plot and regression equation for rates of blended NPS fertilizer as independent variable and total dry fruit yield of individual hot pepper varieties as dependent variable.

\section{Conclusion and Recommendation}

The results of current study revealed that hot pepper varieties showed differential responses for dry fruit yield and yield components when subjected to different rates of blended NPS fertilizer at Arba Minch condition. These suggest that the importance of considering combination of better variety and optimum rate of blended NPS fertilizer to increase the productivity of hot pepper in the study area. Melka Shote showed better vegetative growth performance as compared to the rest two varieties (Bako Local and Mareko Fana). Regarding blended NPS fertilizer effect, application of $200 \mathrm{~kg} \mathrm{ha}^{-1}$ blended NPS fertilizer to hot pepper plants resulted in better growth parameters.

Melka Shote and Bako Local varieties at the application of $200 \mathrm{~kg} \mathrm{ha}^{-1}$ blended NPS fertilizer showed better in all yield and yield components studied and gave minimum unmarketable dry fruit yield. In general, the result of this study revealed that application of $200 \mathrm{~kg}$ of NPS ha ${ }^{-1}$ for Melka Shote and Bako Local varieties produced maximum dry fruit yield that is due to the optimum application of blended NPS fertilizer coupled with yield contributing characters of the two varieties.

Regression analysis also revealed that the response of hot pepper varieties had differences to the applied rates of blended NPS fertilizer of which Melka Shote variety had total dry fruit yield advantages of 1.3 and $2.4 \mathrm{~kg}$ over Bako Local and Mareko Fana, respectively, as the rates of blended NPS fertilizer increased by one $\mathrm{kg}$. Therefore, growing of Melka Shote and Bako Local varieties with the application of $200 \mathrm{~kg} \mathrm{ha}^{-1}$ blended NPS fertilizer would offer the better dry fruit yield to growers of hot pepper in the study area and other areas with similar soil fertility status and agro-ecology.

\section{Acknowledgements}

The authors would like to thank South Agricultural Research Institute and Arba Minch Agricultural Research Center for providing all the necessary working facilities. The authors are also grateful to Bako and Melkassa Agricultural Research Centers for providing planting materials. The authors appreciate the support of Mr. Alemayehu Wodajo during experimental period.

\section{Appendix}

Table 5. Rates of fertilizers and amount of mineral nutrient contents in six levels of blended NPS fertilizer set as treatments for this study.

\begin{tabular}{|c|c|c|c|c|c|c|}
\hline \multirow{2}{*}{ No } & \multirow{2}{*}{$\begin{array}{l}\text { Blended NPS fertilizer } \\
\text { rate }\left(\mathrm{kg} \mathrm{ha}^{-1}\right)\end{array}$} & \multicolumn{3}{|c|}{ Mineral nutrient contents from blended NPS fertilizer $\left(\mathrm{kg} \mathrm{ha}^{-1}\right)$} & \multirow{2}{*}{$\begin{array}{l}\text { N from } 100 \mathrm{~kg} \mathrm{Urea} \mathrm{ha}^{-1} \\
\left(\mathrm{~kg} \mathrm{ha}^{-1}\right)\end{array}$} & \multirow{2}{*}{$\begin{array}{l}\text { Total N (kg } \\
\left.\text { ha }^{-1}\right)\end{array}$} \\
\hline & & $\mathbf{N}$ & $\mathbf{P}_{2} \mathbf{O}_{5}$ & $\mathbf{S}$ & & \\
\hline 1 & 0 & 0 & 0 & 0 & 0 & 0 \\
\hline 2 & 50 & 9.5 & 19 & 3.5 & 46 & 55.5 \\
\hline 3 & 100 & 19 & 38 & 7 & 46 & 65 \\
\hline 4 & 150 & 28.5 & 57 & 10.5 & 46 & 74.5 \\
\hline 5 & 200 & 38 & 76 & 14 & 46 & 84 \\
\hline 6 & 250 & 47.5 & 95 & 17.5 & 46 & 93.5 \\
\hline
\end{tabular}




\section{References}

[1] Bosland, P. and Votava, E., 2000. Peppers, Vegetable and Spice Capsicums. CABI Publishing, New York, USA. Pp: 1-198.

[2] Ethiopian Export Promotion Agency. 2003. Spice Potential and Market Study. Product Development and Market Research Directorate, Addis Ababa, Ethiopia: 1-103.

[3] Central Statistical Agency of the Ethiopia. 2019. Report on Area and Production of Major Crops (Private Peasant Holdings, Meher Season). Agricultural Sample Survey 2017/2018. Volume I, Statistical Bulletin 586. Addis Ababa, Ethiopia.

[4] Lemma Desalegn. 2002. Tomato Research Experiences and Production Prospects. Research Report. Ethiopia Agricultural Research Organization, No. 43, Addis Ababa, Ethiopia.

[5] Abebayehu, A., Misginaw, T., Abraham, B., Solomon, T., Alemayehu, R., Bayu, D. 2014. Influences of Mineral Nitrogen and Phosphorous Fertilization on Yield and Yield Contributing Components in Hot Pepper (Capsicum annuum L.). African Journal of Agricultural Research, 9 (7): 670-675.

[6] Seleshi, D., Derbew, B., Ali, M., and Yehenew, G. 2014. Evaluation of Elite Hot Pepper Varieties (Capsicum spp.) for Growth, Dry Pod Yield, and Quality under Jimma Conditions, South West Ethiopia. International Journal of Agricultural Research, 9: 364-374.

[7] Shiferaw Mekonen and Alemayehu Chala. 2014. Assessment of Hot Pepper (Capsicum species) Diseases in Southern Ethiopia. International Journal of Science and Research, 3(3): 91-95.

[8] Workneh, N., Edilegnaw, W., Almaz, G., and Gezahegn, A. 2014. Constraints of Vegetables Value Chain in Ethiopia. International Journal of Advanced Research in Management and Social Sciences, 3 (12): 44-71.

[9] Tariku, S., Getachew, G., Kanko, C., Alemnesh, A., Abriham, A., Arega, A., and Abayneh, F. (2018). Identifcation and Prioritization of Major Factors that Challenge Crop Productivity and Production System in the Case of Gamo Gofa, Segen Area People Zone and Basketo Special Woreda. Annals of Social Sciences and Management Studies, 1 (1): 001-006.

[10] IAR (Institute of Agricultural Research). 1996. Research Progress Report. Addis Ababa, Ethiopia.

[11] EthioSIS (Ethiopia Soil Information System). 2014. Soil Fertility Status and Fertilizer Recommendation Atlas. Addis Ababa, Ethiopia.

[12] EthioSIS (Ethiopia Soil Information Systems). 2016. Soil Fertility Status and Fertilizer Recommendation Atlas for Southern Nations, Nationalities, and Peoples' Regional State, Ethiopia. EthioSIS, Addis Ababa, Ethiopia.

[13] NMA (National Meteorology Agency: Southern Branch). 2019. Monthly Rainfall, Minimum and Maximum Temperature Data for Arba Minch Zuria District Recorded at Arba Minch Meteorology Station during 2018/2019 Cropping Season obtained from Southern Branch, Hawassa, Ethiopia.

[14] EARO (Ethiopian Agricultural Research Organization). 2004. Directory of Released Crop Varieties and their Recommended Cultural Practices. Ethiopian Agricultural Research Organization, Addis Ababa, Ethiopia.
[15] MoARD (Ministry of Agriculture and Rural Development). 2009. Animal and Plant Health Regulatory Directorate. Crop Variety Register. Issue No. 12. Addis Ababa, Ethiopia.

[16] SAS (Statistical Analysis of Software). 2008. User's Guide. Version 9.2. NC. USA.

[17] Kahsay Yemane. 2017. Evaluation of Hot Pepper Varieties (Capsicum species) for Growth, Dry pod Yield and Quality at $\mathrm{M} /$ Lehke District, Tigray, Ethiopia. International Journal of Engineering Development and Research, 5 (3): 144-152.

[18] El-Tohamy, W. A., Ghoname, A. A. and Abou-Hussein, S. D. 2006. Improvement of Pepper Growth and Productivity in Sandy Soil by Different Fertilization Treatments under Protected Cultivation. Journal of Applied Science Research, 2: 8-12.

[19] Awodun, M. A., Omonijo, L. I., and Ojeniyi, S. O. 2007. Effect of Dung and NPK Fertilizer on Soil and Leaf Nutrient Content, Growth and Yield of Pepper. International Journal of Soil Science, 2 (2): 142-147.

[20] Rizvi, I. M., Tania, S., Ahsanul, H. M., Ismail, H. M., Naima, S. and Rabiul, I. 2018. Growth and Yield of Chilli Influenced by Nitrogen and Phosphorus. IOSR Journal of Agriculture and Veterinary Science, 11 (5): 54-68.

[21] Kassa Melese, Wassu Mohammed and Gebre Hadgu. 2018. Response of Hot Pepper (Capsicum annuum L.) as Affected by NP Fertilizer and Farmyard Manure Combined Application in Raya Azebo District, Northern Ethiopia. International Journal of Life Sciences, 6 (4): 831-848.

[22] Kanneh, S. M., Musa, P. D., Osei, M. K., Quee, D. D., Akromah, R. and Lahai, M. 2017. Response of Different NPK Fertilizer Rates on the Growth and Yield of Two Local Varieties of Pepper (Capsicum annuum L.) in Ogoo Farm, Western Area, Sierra Leone. Asian Research Publishing Network: Journal of Agricultural and Biological Science, 12 (4): 123-127.

[23] Zaki, M. F., Fawzy, Z. F., Ahmed, A. A. and Tantawy, A. S. 2012. Application of Phosphate Dissolving Bacteria for Improving Growth and Productivity of Two Sweet Pepper (Capsicum annuum L.) Cultivars under Newly Reclaimed Soil. Australian Journal of Basic and Applied Sciences, 6 (3): 826839.

[24] Poornima, K. S. 2007. Effect of Potassium and Sulfur on Yield and Quality of Onion and Chilli Intercrops in a Vertisol. MSc Thesis Submitted to the University of Agricultural Sciences, Dharwad, Karnataka, India.

[25] Uchida, R. 2000. Essential Nutrients for Plant Growth: Nutrient Functions and Deficiency Symptoms. In: Silva J. A. and Uchida R. (Eds.), Plant Nutrient Management in Hawaii's Soils, Approaches for Tropical and Subtropical Agriculture. College of Tropical Agriculture and Human Resources, University of Hawaii at Manoa.

[26] Wakuma, B. 2018. Growth and Yield Response of Hot Pepper (Capsicum annuum L.) to Blended Fertilizer Rates and Cultivars in Raya Azebo, Northern Ethiopia. MSc Thesis, Jimma University, Jimma, Ethiopia.

[27] Fufa Nimona and Abera Girma. 2019. Effects of Blended Fertilizer Types and Rates on Fruit Yield and Nutrient Use Efficiencies of Hot Pepper (Capsicum annuиm L) at Assosa, Western Ethiopia. African Journal of Agricultural Research, 14 (33): 1737-1748. 